\title{
REVIEW
}

\section{A cross-system analysis of labile dissolved organic carbon*}

\author{
Morten Søndergaard, Mathias Middelboe \\ Freshwater Biological Laboratory, University of Copenhagen, Helsingersgade 51, DK-3400 Hillerød, Denmark
}

\begin{abstract}
The utilization of dissolved organic carbon (DOC) by bacteria in grazer-free cultures can be used to measure the concentration of labile $D O C\left(D O C_{L}\right)$. A database of 126 measurements was used to test whether or not the concentration of $\mathrm{DOC}_{\mathrm{L}}$ is positively related to total $\mathrm{DOC}$. A positive and significant correlation between $\mathrm{DOC}_{\mathrm{L}}$ and $\mathrm{DOC}$ was found for the entire database as well as for lakes, rivers and seawater. An average response of about $0.17 \mu \mathrm{mol} \mathrm{DOC}_{\mathrm{L}} \mu \mathrm{mol}^{-1} \mathrm{DOC}$ could be calculated and $60 \%$ of the variance was explained by DOC. The DOC $L$ concentration averaged 14,19 , and $19 \%$ of the total DOC pool in lakes, rivers and seawater, respectively, however, the median value of $25 \%$ for rivers was about twice the values for lakes and seawater The high relative amount of $D O C_{L}$ in half the rivers was explained by anthropogenic influence. The control of $\mathrm{DOC}_{\mathrm{L}}$ concentrations was analyzed according to models of bacterial and substrate interactions applying Michaelis-Menten-Monod kinetics. It is suggested that the higher concentrations of $D O C_{L}$ in eutrophic as opposed to oligotrophic systems may be explained by a higher 'theoretical community half-saturation constant' $\left(K_{\mathrm{s}}\right)$ in eutrophic systems. The consequence of a higher $K_{\mathrm{s}}$ will be a higher steady-state concentration of labile substrate, as was found. Other possible explanations were analyzed, but rejected as major causes for the crosssystem difference.
\end{abstract}

KEY WORDS: Labile DOC · Cross-system differences · Control of labile DOC

\section{INTRODUCTION}

Most organic material in oceans, freshwater lakes, and rivers occurs in a dissolved form (Birge \& Juday 1934, Krogh 1934a, Hedges 1992). Birge \& Juday (1934) arrived at the conclusion that in inland lakes without major external sources of organic matter, the weight of solutes was constantly about 5 to 6.5 times that of the plankton. On a global scale, the pool of dissolved organic carbon (DOC) is about the same magnitude as atmospheric $\mathrm{CO}_{2}, 0.6 \times 10^{18} \mathrm{~g} \mathrm{C}$, and accounts for some $20 \%$ of the organic material on the globe (excluding kerogen and coal; Hedges 1992). The major part is present in the vast volume of the oceans. An understanding of the dynamics of the

- Contribution no. 613 from Freshwater Biological Laboratory, University of Copenhagen
DOC pool is a prerequisite for modelling the global carbon cycle.

A distinction between particles and true solutes is difficult due to a continuum of particle sizes (Sharp 1973), and it has become common practice to define DOC from an operational standpoint using a glass fiber filter (e.g. Whatman GF/F filters; Nagata \& Kirchman 1992, Sharp 1993). Colloids and small particles on one hand pass the filter (Lee \& Fuhrman 1987, Søndergaard \& Middelboe 1993), but are also adsorbed (Johnson \& Wangersky 1985). Therefore, an operative definition of DOC is somewhat elusive (Kepkay 1994).

The perception that most DOC is highly recalcitrant and dominated by large molecules, e.g. $>10000 \mathrm{Da}$ (Ogura 1972, Allen 1976, Cole et al, 1984), has been challenged by the accumulation of evidence that large molecules in the ocean can be more bioreactive than small molecules ( $<1000 \mathrm{Da})$ and that small molecules can comprise some $70 \%$ of the DOC in both marine 
(Carlson et al. 1985, Amon \& Benner 1994) and freshwater locations (Søndergaard \& Schierup 1982, Hama \& Handa 1983, Søndergaard 1984, Søndergaard \& Borch 1992). The recalcitrant nature is also a relative perception, as between 10 to $40 \%$ of the ambient pool can be available for decomposition by bacteria. These results are mainly attributed to the euphotic zones of oceans and relatively shallow lakes (Søndergaard et al. 1995). The bioavailable pool may be lower in unpolluted rivers (Mantoura \& Woodward 1983).

The large reservoir of energy and nitrogen fand phosphorus) present in the dissolved pool was generally accepted early this century, although overestimated for analytical reasons. This led Pütter (1908, 1911) to formulate the hypothesis that direct uptake from the dissolved phase was the main source of food for all types of aquatic animals. This hypothesis was considered to have been disproven by Krogh (1930), but more recent results concerning DOC utilization by invertebrates have re-opened the discussion (Sepers 1977). The investigations concerning bacterial regrowth in filtered water from lakes and oceans even made Krogh suggest that 'dissolved organic matter is not a suitable bacterial food' (Krogh 1934a). He explained his own observations on regrowth of bacteria and oxygen utilization in filtered water as having been caused by some unknown stimulation due to handling in the laboratory (Keys et al. 1935). However, it was acknowledged that bacteria and naked protozoans, due to their large surface/volume ratios, were the only organisms potentially able to utilize DOC. It also seems worth mentioning that Krogh actually included the presence of a microbial loop in his contemporary description of the 'ultimate food cycle in the sea' (Krogh 1934b).

The results from new methods of measuring bacterial abundance (Hobbie et al. 1977) and production (Fuhrman \& Azam 1980) showed that a substantial part of planktonic primary production (20 to $50 \%$ ) is routed through a dissolved phase and metabolized by bacteria in the microbial loop (Williams 1981, Azam et al. 1983, Cole et al. 1988). Orily small molecules like amino acids and glucose, and short peptide chains (Payne 1976, Coffin 1989), can actively be transported across bacterial cell membranes with high affinity permeases. Therefore, bacterial production must be fuelled by a fast flux of small molecules with short turnover times, as the high-affinity transport systems (low half-saturation constants) keep the compounds at very low ambient concentrations (Crawford et al. 1974, Billen et al. 1980. Hagström et al. 1984, Fuhrman \& Ferguson 1986). Bacterial extracellular enzymes are an important mechanism generating low molecular weight DOC for bacterial assimilation and enzyme synthesis/activation may be the rate-limiting step in control- ling bacterial production (Billen 1990). The concentration of easily assimilated low molecular weight substrates only adds up to a few percent of total DOC (Lee \& Wakeham 1992) and cannot account for the size of the labile pool measured in decomposition experiments (Ogura 1972, 1975).

The synthesis of such information produced the current perception that the lability of DOC can be described by a continuum of pools with successively decreasing decomposition constants resulting in turnover times from hours to days, weeks, months and years (Ogura 1975, Aminot et al. 1990). Thus there is a range of conditions, from extremely labile substrates with turnover times of minutes and hours (Fuhrman \& Ferguson 1986, Coffin et al. 1993) to the (almost) inert deepocean DOC (Barber 1968). Polymer carbohydrates and proteins are probably the main constituents of the dynamic pool (Billen 1984, Pakulski \& Benner 1994).

Temporal within-system variations of both total DOC and labile DOC have been found with timescales of hours, showing predictable diel variations (Sieburth et al. 1977, Kaplan \& Bott 1982, Søndergaard 1984, Bertoni 1986, Zweifel et al. 1993), days (Kirchman et al. 1991, Middelboe \& Søndergaard 1993), weeks (Brockmann et al. 1979, Ittekot 1982, Billen \& Fontigny 1987 , Søndergaard \& Borch 1992), and seasons (Duursma 1963, Wafar et al. 1984).

Moreover, direct measurements of the labile pool of DOC have provided evidence of variations both within (Jonas \& Tuttle 1990, Kirchman et al. 1991, Søndergaard \& Borch 1992) and among systems (Tranvik 1988, Sondergaard \& Borch 1992). The bioavailable pool provides energy and carbon for a proliferation of bacteria during regrowth in filtered water and is, in this investigation, termed labile $\mathrm{DOC}\left(\mathrm{DOC}_{\mathrm{L}}\right)$. In the context presented here, 'labile' is used to indicate the amount of DOC which can be decomposed by bacteria within a week or two. The definition is thus somewhat arbitrary, but is in essence an approximation to the first decomposition rate constant suggested by Ogura (1972, 1975) and Aminot et al. (1990), and to the sum of the L1 and L2 pools used by Connolly et al. (1992). The effects of photolytic DOC degradation or other abiotic mechanisms, which make otherwise recalcitrant molecules bioavailable, are not included in the definition, although these mechanisms seem of major importance for the global DOC turnover (Hedges 1992).

Previous studies on $\mathrm{DOC}_{\mathrm{L}}$ in freshwater and some coastal areas (Søndergaard 1984, Servais et al. 1987. Tranvik 1988, Middelboe et al. 1992, Søndergaard \& Borch 1992) suggested the concentration of $D O C_{L}$ was positively related to the concentration of total DOC. It is the purpose of the present review to examine whether or not a predictable cross-system difference in $\mathrm{DOC}_{\mathrm{L}}$ concentrations is present. 


\section{METHODS}

The approach used in $\mathrm{DOC}_{L}$ measurements is to remove all organisms except bacteria from a water sample and allow the bacteria to grow and reach the carrying capacity with respect to the carbon, nitrogen or phosphorus sources available. So, basically all experiments over the years have used reasonably similar methodologies. By filtration (e.g. $0.2 \mu \mathrm{m}$ pore size filters) most or all bacteria in a water sample are removed and an inoculum of native bacteria is supplemented in low quantities ( 3 to $10 \%$ ). Alternatively, a filter with a pore size which removes all organisms but bacteria (and viruses) is used to prepare the culture. The pore size chosen is often between 0.6 and $2.0 \mu \mathrm{m}$. The culture is now incubated in the dark at in situ or some fixed temperature. The regrowth and metabolism of bacteria and the disappearance of DOC are followed over time. Such a procedure was used by Krogh \& Lange (1932) and is still used today (Servais et al. 1987, Coffin et al. 1993, Søndergaard et al. 1995), although the methods to measure bacterial abundance, respiration and DOC obviously have changed.

A theoretical regrowth experiment is presented in Fig. 1 as a typical example from a eutrophic lake (Søndergaard \& Borch 1992). Although the decomposition of DOC can be described by a continuum of decreasing rate constants (Ogura 1975), there seems to be an unspoken consensus to define the term labile DOC as the first plateau level reached by the concentration of DOC or alternatively by bacterial biomass (Servais et al. 1987, Tranvik 1988, Kirchman et al. 1991). This definition was adopted here for the collection of literature data. Using an inoculum of about 5 to $10 \%$ of the original bacterial density and a temperature of 15 to $20^{\circ} \mathrm{C}$, the endpoint is normally reached within 5 to $7 \mathrm{~d}$ or less.

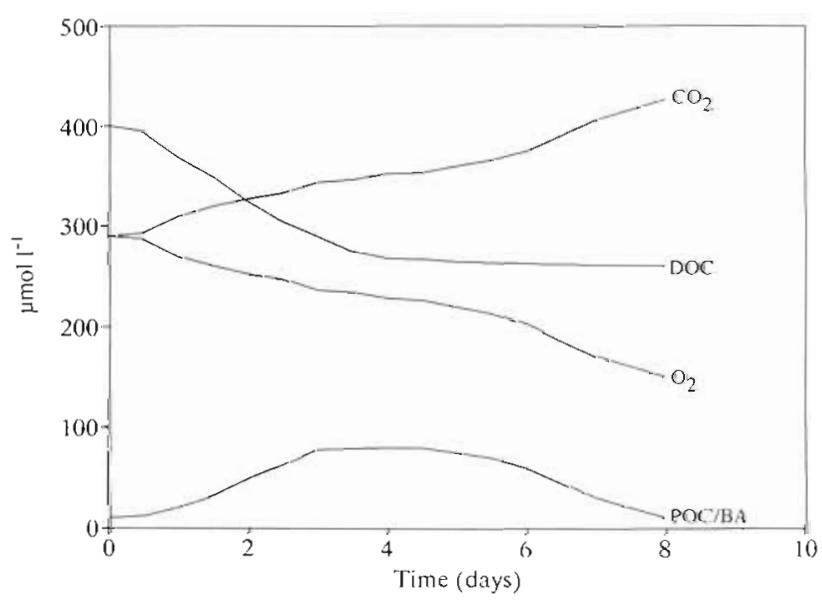

Fig. 1. Example of a theoretical bacterial regrowth experiment exemplifying possible output signals
Connolly et al. (1992) described breaks in the oxygen utilization curve related to the apparent lability of the substrate, however a general occurrence of this phenomenon in aquatic systems has yet to be shown.

From Fig. 1 it is apparent that various methods can be used to measure or calculate $\mathrm{DOC}_{\mathrm{L}}$. The most direct and unequivocal method is to measure the decrease in DOC. However, with a high background concentration of recalcitrant DOC and perhaps a relatively small labile pool, the results can be rather uncertain. Alternatively, many authors have measured respiration using oxygen or inorganic carbon and the production of bacterial biomass. The biomass is either measured directly as particulate organic carbon (POC) or by cell counting, biovolume estimations, and then calculation of the carbon biomass by a carbon per volume conversion factor. Each procedure has its strengths and weaknesses. A detailed discussion is outside the purpose of this review, but a few major problems will be outlined.

It is difficult to omit heterotrophic flagellates from dilution and regrowth experiments, however, their presence does not necessarily violate the estimation of $\mathrm{DOC}_{\mathrm{L}}$ unless they produce recalcitrant DOC and/or unavailable colloids during grazing (Johnson \& Kepkay 1992, Nagata \& Kirchman 1992), or they produce new labile material. Absence of flagellates is desirable in regrowth experiments.

If the purpose of the experiment is to measure the carrying capacity controlled by the pool of organic carbon as such and not the exhaustion of inorganic nutrients, a surplus of inorganic nutrients must be present. This prerequisite is not always evidenced in published results. Furthermore, the respiratory quotient (RQ) has to be known or estimated when oxygen is used to measure respiration. If ammonium is present, more than $10 \%$ of the oxygen utilization can occasionally be explained by nitrification during prolonged incubations (Fig. 2). We have used an $\mathrm{RQ}$ value of $0.82 \mathrm{~mol}$ $\mathrm{CO}_{2} \mathrm{~mol}^{-1} \mathrm{O}_{2}$ (Søndergaard \& Borch 1992) to convert oxygen to carbon equivalents.

The use of bacterial abundance and biovolume and the conversion to biomass is a difficult and uncertain procedure, although widely applied. Thus, direct measurements of DOC, POC and inorganic carbon are to be preferred. In studies which presented only abundance and/or cell biovolumes, we have used $35 \mathrm{fg} \mathrm{C}$ cell $^{-1}$ or the size-dependent carbon per volume relationship presented by Simon \& Azam (1989). The

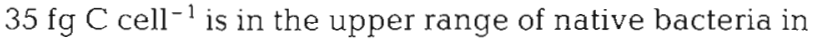
the oceans, but is a reasonable value for freshwater bacteria. It is apparent that bacteria in regrowth experiments are often rather large (e.g. Ammerman et al. 1984, Tranvik 1988, Kroer 1993, Søndergaard \& Middelboe 1993, Tulonen 1993). 


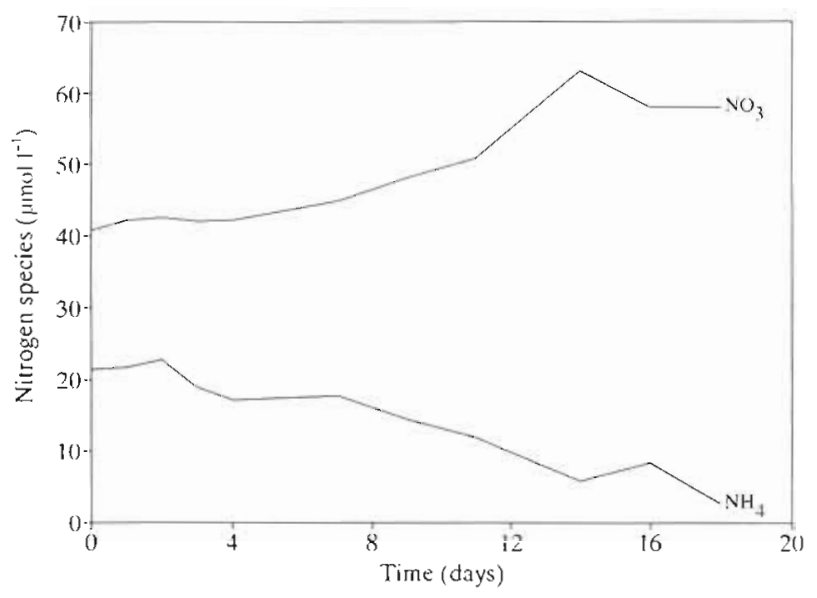

Fig. 2. Time course of nitrate and ammonium during a decomposition experiment. The stoichiometry between nitrate increase and ammonium decrease averaged 0.96 . Frederiksborg Slotsso, December 1991

To prevent substantial wall growth in the incubation chambers, relatively large containers have to be used and the incubation time has to be relatively brief (Kristiansen et al. 1992, Søndergaard et al. 1995), otherwise the measurement of bacterial biomass could be jeopardized. However, Ammerman et al. (1984) concluded that wall growth of marine bacteria was unimportant during $3 \mathrm{~d}$ of incubation in $125 \mathrm{ml}$ Erlenmeyer flasks.

Wall growth is a part of the question of how to interpret the activity and physiological performance of a bacterial community developing in a batch culture compared with the diversity of those actually active in nature. The problem might partly be circumvented with the use of an (almost) intact native bacterial community (Kirchman et al. 1991, Coffin et al. 1993). However, both batch and chemostat incubations will present an artificial selective pressure. To what extent DOC $_{L}$ measurements will be affected is unknown, but unless the bacteria growing in the cultures are very different from the native community in their biochemical and physiological performances, the measured quantity of $\mathrm{DOC}_{\mathrm{L}}$ should not change.

The results presented below are mainly collected from the available literature and a few by personal communication. As the methods used to measure DOC and $\mathrm{DOC}_{\mathrm{L}}$ are different and no standard procedures are available, we have not discriminated against 'older' results. It should also be noted that although a DOC measuring controversy has been in focus for some years, the most recent intercomparisons of DOC measurements have not presented clear evidence that any single method (wet oxidation or high temperature combustion) is to be preferred with respect to accuracy and precision (Sharp 1993, Sharp et al. 1993). However, errors from variable blank subtraction proce- dures can probably account for some of the scatter in low-carbon seawater (see Fig 6). A few results have been deleted due to errors in DOC values made obvious by the present knowledge on accuracy of DOC measurements (Sharp 1993, Sharp et al. 1993). If seasonal or long time series within a single location are available (e.g. Søndergaard \& Borch 1992), a weighted average compensating any bias for season and a particular location have been used. Repeated observations are not presented, except for a single system as specified, and no repeated observations are used in any statistical treatments. Studies on the decomposition of specific molecules or size classes of molecules are not included. Furthermore, articles claiming $D \mathrm{C}_{\mathrm{L}}$ measurement in unfiltered samples with an intact biota have been omitted, as discrimination between respiration by bacteria and that of other organisms cannot be made, and the production of new DOC during incubation is likely to have taken place. The only exceptions are results ( 3 cases) presenting solid evidence for diel in situ variations of $\mathrm{DOC}$. The difference between minimum and maximum DOC concentrations can be viewed as a minimum estimate of a labile pool with a high turnover rate (see example in Fig. 4).

Apart from the measured diel DOC variations, the very high initial bacterial respiration found by Coffin et al. (1993) gives credit to the suggestion that a superlabile pool with turnover times of minutes or a few hours can be present. Therefore, samples for $\mathrm{DOC}_{\mathrm{L}}$ measurements should be processed immediately upon collection and the solar cycle should be taken into account. However, due to very short turnover times the concentration of substrates in such a pool must be low at most times. Amino acids and monosaccharides are likely candidates for such super-labile substrate, with low in situ concentrations compared to measured $\mathrm{DOC}_{\mathrm{L}}$ values (Billen et al. 1980, Fuhrman \& Ferguson 1986, Jørgensen \& Jensen 1994). This emphasizes that DOC $C_{L}$ cannot be considered a variable directly related to bacterial production and the in situ flux of bacterial substrate.

Our sampling of the literature and unpublished results made available by colleagues provided 38 useful references with 126 pairs of data. The publications span from 1932 to 1994 and include 34 datapoints from lakes, 34 from rivers and 58 from marine stations. Exclusion of repeated measurements within a system reduced the used data to 27,12 and 38 for lakes, rivers and seawater, respectively. About $60 \%$ of the data were published after 1990. Direct measurements of $\mathrm{DOC}_{\mathrm{L}}$ could be extracted in about $65 \%$ of the cases, while assumptions concerning bacterial biomass and/or growth yield were used for the remaining data. Literature not specifically mentioned in the text but used as a source for data is included in the list of refer- 
ences (i.e. Ochiai et al. 1980, Tranvik \& Hofle 1987, Servais et al. 1989, Wells \& Goldberg 1991, Findlay et al. 1992, Bodungen \& Kahler 1994, Hagström \& Blackburn 1994, Kahler et al. 1994, Sanders et al. 1994). Statistical analysis included geometric mean (Type II) regressions on log-log transformed data (Sokal \& Rohlf 1981), thus allowing variability in both DOC and $\mathrm{DOC}_{\mathrm{L}}$.

\section{RESULTS}

The results from freshwater lakes included 27 datapoints and a log-log scatterplot is presented in Fig. 3. Values of both DOC and $D^{\circ O C}$ varied by a factor of about 15, from 180 to $3000 \mu \mathrm{mol} \mathrm{l^{-1 }}$ and 12 to $200 \mu \mathrm{mol}^{-1}$, respectively. It is apparent from the plot that $D O C_{L}$ correlated positively with DOC. One result from a humic lake (Søndergaard unpubl.) stands out as an obvious outlier. The calculated correlation was significant, both including and excluding the outlier ( $\mathrm{p}<$ $0.01)$. The slope of the regression indicated a response of $0.22 \mu \mathrm{mol} \mathrm{DOC}_{\mathrm{L}} \mu \mathrm{mol}^{-1} \mathrm{DOC}$. The scatter, however, only allowed $38 \%$ of the variability to be explained by DOC.

As mentioned in the introduction, $\mathrm{DOC}_{L}$ can show both short-term (days) and long-term (weeks) variations, which can provide some of the scatter. The amount of scatter may be exemplified by results from a eutrophic lake (Fig. 4), where $D O C_{L}$ varied by a factor of 2 within a few weeks (Søndergaard et al. 1995). A calculation of the theoretical turnover time based on in situ bacterial production measured by thymidine incorporation and a constant growth yield of 0.35 (Middel-

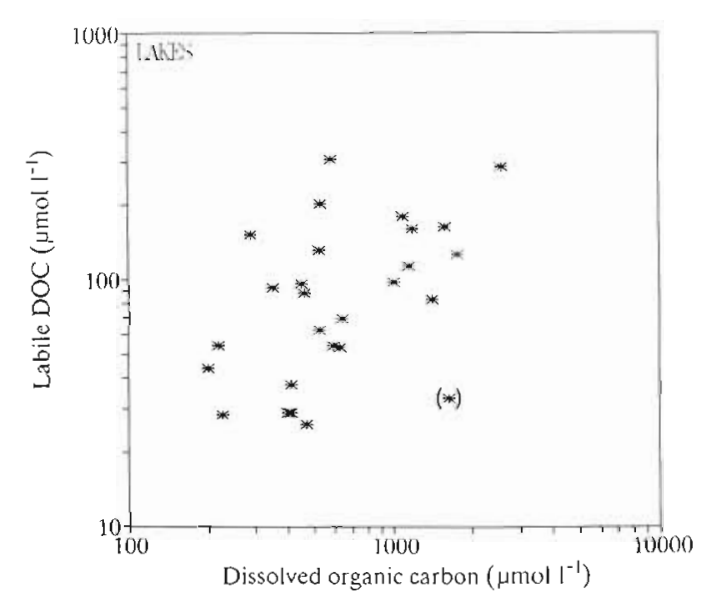

Fig. 3. Scatter plot of labile DOC versus total DOC in lakes. ( ): outlier. Type II $\log -\log$ regression without outlier: $\log y=$ $-1.47 \pm 0.48+1.19 \log x \pm 0.17, \mathrm{p}<0.01, \mathrm{df}=25$

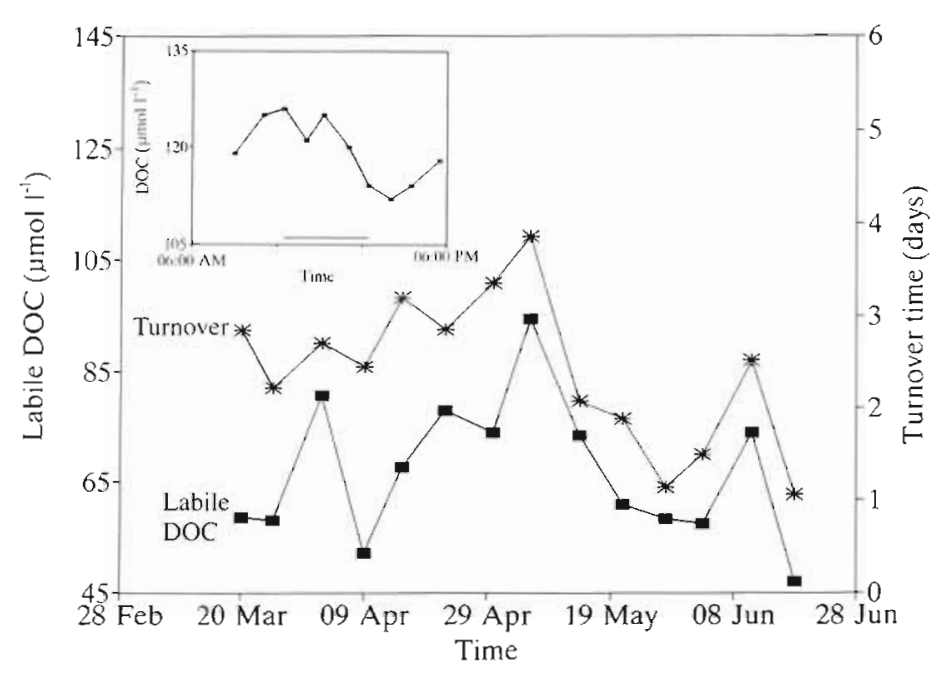

Fig. 4. Labile DOC and calculated labile DOC turnover times in eutrophic Frederiksborg Slotssø (after Sondergaard et al. 1995). Insert: an example of diel DOC variations in seawater (after $Z$ weifel et al. 1993)

boe et al. 1992) revealed variations in turnover time from 1 to $4 \mathrm{~d}$ (Fig. 4). This signifies that the major part of measured $\mathrm{DOC}_{\mathrm{L}}$ does not belong to a super-labile pool. $\mathrm{DOC}_{L}$ variations of a similar magnitude, but with a timescale of a few days, have been found in both lakes and marine locations (Kirchman et al. 1991, Middelboe \& Søndergaard 1993). An example of diel DOC variations is inserted in Fig. 4 for comparison.

The river data showed 2 distinct clusters (Fig. 5). The results from different sampling points along the 'blackwater' Ogeechee River (Georgia, USA) clearly stand out from the rest due to very low concentrations of $\mathrm{DOC}_{\mathrm{L}}$ (Leff \& Meyer 1991). The remaining data covered a factor of 20 in DOC and a factor of 100 in $D_{\mathrm{L}}$

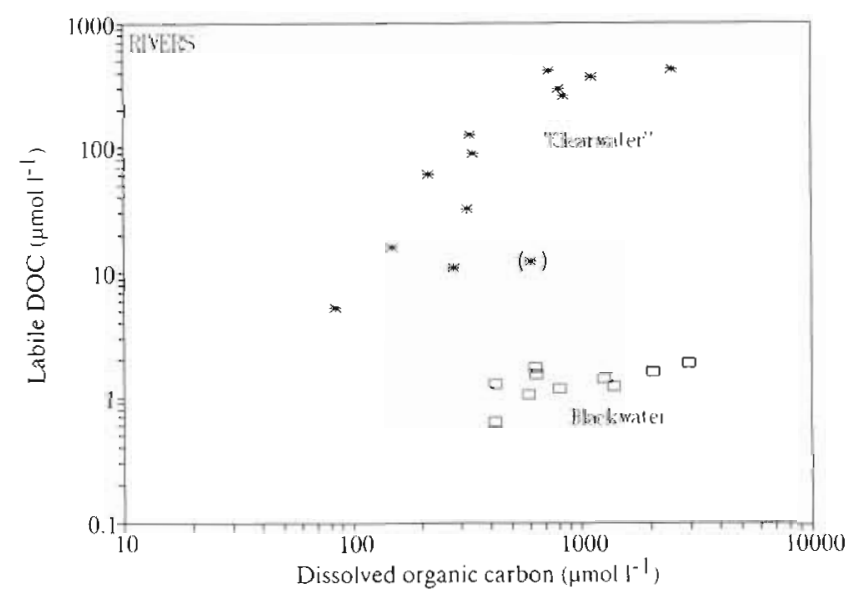

Fig. 5. Scatter plot of labile DOC versus total DOC in rivers. (): outlier. Type II log-log regression without blackwater and outlier: $\log y=-2.16 \pm 0.55+1.56 \log x \pm 0.21, \mathrm{p}<0.01, \mathrm{df}=10$ 


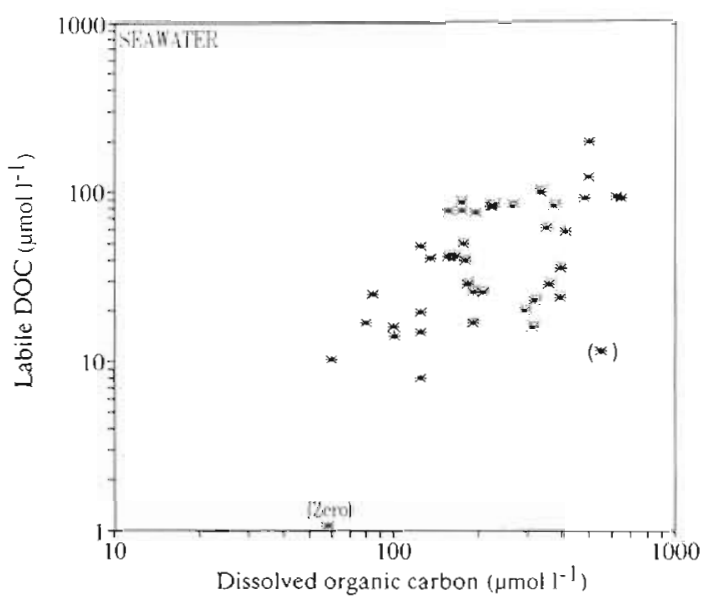

Fig. 6. Scatter plot of labile DOC versus total DOC in seawater. ( ): outlier. Type II log-log regression without outliers: $\log y=-2.02 \pm 0.41+1.56 \log x \pm 0.18, p \ll 0.01, \mathrm{df}=36$

values. Except for 1 obvious outlier, the scatter for the 'clear-water' rivers was less pronounced than for the lake samples and a significant regression $(p<0.01)$ emerged despite the lower degrees of freedom. The calculated slope was similar to the lake data, giving a response of about $0.17 \mu \mathrm{mol} \mathrm{DOC}_{\mathrm{L}} \mu \mathrm{mol}^{-1} \mathrm{DOC}$. About $81 \%$ of the variability was explained by DOC. No significant correlation could be calculated for the blackwater river data.

The 38 data from marine areas covered both blue ocean waters and highly productive coastal areas and varied by a factor of about 10 for DOC and slightly more for DOC $\mathrm{C}_{\mathrm{L}}$ (Fig. 6). Of the data points, 2 or 3 stand out as outliers. Barber's (1968) measurements from

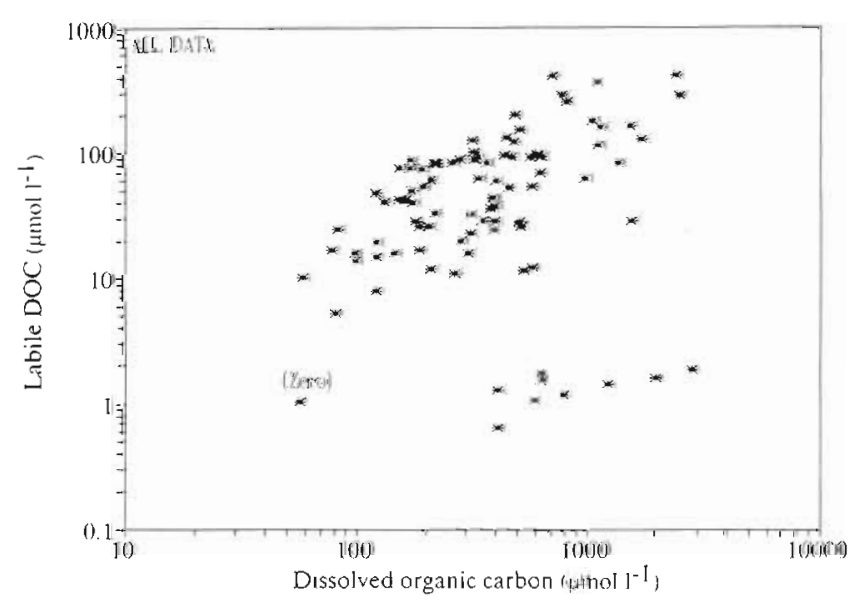

Fig. 7. Scatter plot of all data of labile DOC versus total DOC. Type II log-log regression without blackwater river and outliers marked in Figs. 3, $5 \& 6: \log y=-1.39 \pm 0.24+1.24 \log x$ $\pm 0.09, \mathrm{p}<0.01, \mathrm{df}=75$ deep Atlantic waters were actually zero, but are presented here as a small positive number. The other outlier is from the same study that produced the obvious outlier for the river data. The study is recent and the labile pool was measured as DOC decrease over a few days with a 'state of the art' method. If some systematic error was not present, and nothing indicates this is so, it is difficult to explain the low concentrations of $\mathrm{DOC}_{\mathrm{L}}$. Including or excluding the outliers did not dramatically alter the correlation although the variability explanation increased from about $25 \%$ to $45 \%$ by their exclusion. The regression was highly significant $(\mathrm{p} \ll 0.01)$ and the response was about $0.25 \mu \mathrm{mol} \mathrm{DOC}_{\mathrm{L}} \mu \mathrm{mol}^{-1}$ DOC.

The inclusion of all data into 1 mutual scatter-plot, but excluding the blackwater river and outliers in the calculation, showed a highly significant correlation ( $p \ll 0.01$ ) and an explanation of variance approaching $60 \%$ (Fig. 7). The theoretical $y$-intercept was close to zero and the calculated response was $0.17 \mu \mathrm{mol}^{\mathrm{DOC}} \mathrm{L}$ $\mu \mathrm{mol}^{-1} \mathrm{DOC}$.

Despite the expected scatter caused by methodological differences and within-system variability, the compilation of these cross-system data clearly showed that the concentration of $D O C_{L}$ is higher in systems with higher total DOC. If systems with a high allochthonous input of organics like humic lakes and some rivers are excluded, the concentration of DOC can be viewed as a predictor of plankton densities and productivity (Birge \& Juday 1934, Søndergaard 1984, Peltzer 1994). Accordingly, the ambient pool of $\mathrm{DOC}_{\mathrm{L}}$ has a higher concentration in eutrophic than in oligotrophic systems.

Although a mutual slope for all data can be computed with reasonably high precision (Fig. 7), a difference between lakes and marine environments on one hand and rivers on the other was apparent. The average $D O C_{L}$ percentages of total DOC were not significantly different among the 3 systems, however, the median value of $25 \%$ for the rivers was about twice the values for lakes and seawater (Table 1). The labile pool was less than $1 \%$ in the blackwater river. The frequency distribution of observations showed $60 \%$ of the data from lakes to have $\mathrm{DOC}_{L}$ percentages lower than $12.5 \%$ (Fig. 8). The distribution of marine data had $60 \%$ of the observations lower than $17.5 \% \mathrm{DOC}_{\mathrm{L}}$.

Table 1. Labile DOC as a percentage of total DOC

\begin{tabular}{lccc|}
\hline Environment & Average \pm SD & Median & $N$ \\
\hline Lakes & $14 \pm 8$ & 12 & 27 \\
Rivers & $19 \pm 16$ & 25 & 16 \\
Marine & $19 \pm 12$ & 14 & 36 \\
\hline
\end{tabular}




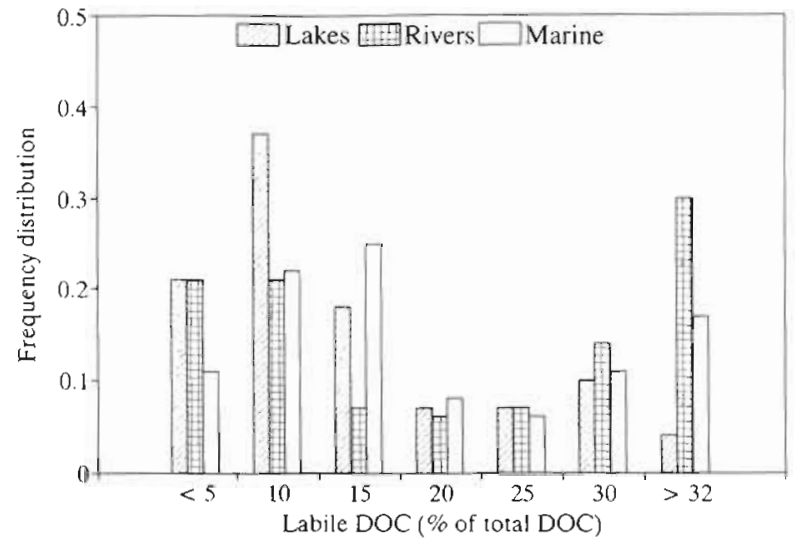

Fig. 8. Frequency distribution of percentage labile DOC in lakes, rivers and seawater

while the rivers had a very uneven frequency distribution with $50 \%$ of the observations larger than $25 \%$ (Fig. 8).

\section{DISCUSSION}

The carrying capacity with respect to biomass within a given aquatic system is basically controlled by the load of nutrients, although deviations from the theoretical level and the qualitative composition of the biota can be influenced by the structure of the food web (Carpenter et al. 1985). Grazer control of phytoplankton might leave unexploited inorganic nutrients in solution. This general description also applies at the level of microbial biomass: high-productivity systems have a higher bacterial biomass than low-productivity systems (Riemann \& Søndergaard 1986, Billen et al. 1990). The concept is intuitively acceptable: autotrophic production can be viewed as directly or indirectly representative of a substantial part of the available food source for bacteria. Allochthonous organic sources may also contribute to a high bacterial biomass, especially in humic lakes (Borsheim et al. 1988, Tranvik 1988). Following the analogy with phytoplankton and inorganic nutrient concentrations, it seems less obvious why high concentrations of an ambient pool of labile DOC should have a positive relationship with high bacterial biomass and high total DOC concentrations. The empirical evidence presented here for such a relationship seems strong.

The changes in the concentration of $D O C_{L}$ must be a function of its rate of production $(P)$ and consumption (C):

$$
\frac{\mathrm{dDOC}_{\mathrm{L}}}{\mathrm{d} t}=P-C
$$

Accordingly, any situation creating temporal imbalances between $P$ and $C$ will result in fluctuating $D O C_{L}$ concentrations. The autochthonous production of DOC and thus $\mathrm{DOC}_{\mathrm{L}}$ is dominated by extracellular products released by algae (EOC), cell lysis at senescence or viral attack, and DOC generated by grazing (see Riemann \& Sondergaard 1986, Jumars et al. 1989). There is no reason to suggest that the plankton present at different nutrient levels generally should produce substrates of different quality. However, it is known that different algal species can release different substrates and that the chemical composition of EOC can be related to the growth phase and the physiological state of the algae. Polysaccharides released by stationary phase diatoms (reviewed by Williams 1990) are one example. To what extent such changes and also seasonal changes in the composition of released products affect measured $D O C_{L}$ is unknown. Likewise the influence of macrophytes in shallow-water systems is unknown and warrants further study. Most probably the variability within a given system is constrained to a factor of about 2 for the measured $\mathrm{DOC}_{\mathrm{L}}$, as exemplified in Fig. 4 and found in seasonal studies (Søndergaard \& Borch 1992). The organic products released will be utilized by different processes, with variable rates and affinities. Monomers and to some extent short peptide chains are directly transported over membranes (Coffin 1989), while larger polymers first have to be hydrolyzed (Chróst 1990). Thus, extracellular enzymes could also be viewed as $\mathrm{DOC}_{\mathrm{L}}$ generators. The production of substrate will not be discussed further, as no models are available to predict quantities and variations in time and space.

Bacterial consumption of simple organic compounds can be described by classical Michaelis-Menten kinetics (Wright \& Hobbie 1966), which relate substrate uptake to the external concentration and the half-saturation constant $\left(K_{s}\right)$. A linkage to growth and biomass production is achieved with the application of a growth yield coefficient and a coefficient taking account of any other rate-limiting factors, such as the accessibility of e.g. nitrogen and phosphorus. Although the use of Michaelis-Menten kinetics in an environment with a diverse bacterial community is constrained for theoretical reasons (Williams 1973), the approach has been adapted rather succesfully to describe bacterial uptake of DOC (Bell 1980, Billen et al. 1980, Connolly et al. 1992). The reasons are that the affinity toward the substrate of the dominant microbial populations is characterized and that the function of extracellular enzymes hydrolyzing polymers can be described by MichaelisMenten kinetics (Billen 1984).

Models describing control of bacteria by substrate supply and grazing (mortality) were developed by Wright et al. (1987), Wright (1988) and Billen et al. (1990) and can be used as first approximations to analyze variations in $\mathrm{DOC}_{\mathrm{L}}$ concentrations, as $\mathrm{DOC}_{\mathrm{L}}$ by 
definition can be considered an immediately available substrate. At steady state both models predict bacterial biomass to be proportional to substrate production and the concentration of substrate to be positively related to $K_{\text {s. }}$. Billen et al. (1990) actually stated that the concentration of substrate is dependent only on $K_{s}$, while Wright's model (1988) predicted that high grazing and grazer control of bacteria would result in the accumulation of a usable substrate pool. Billen did not exclude the effect of grazers, but he proposed resource availability to be the stronger and more general crosssystem control of bacterial biomass. Wright (1988) also stated that periods with unused substrate would be transient (hours to a few days) due to a fast response in bacterial substrate uptake and a higher growth rate at higher substrate concentrations. Bacterial growth rates of 2 to $4 \mathrm{~d}^{-1}$ (Connolly et al. 1992, Morris \& Lewis 1992) clearly support the point, and a return to steady state after perturbation is of the order of 1 generation time (Billen et al. 1980). The weak cross-system pattern observed between bacterial and heterotrophic nanoflagellate abundance does not support a hypothesis of stronger bacterial grazer control in eutrophic as opposed to oligotrophic systems (Gasol \& Vaqué 1993), which, if present, would result in higher $D O C_{L}$ in eutrophic systems according to the models. In conclusion, this leaves $K_{\mathrm{s}}$ as the most likely candidate for controlling substrate concentrations on a timescale longer than days.

Two comments should be added to the use of these models. First, the models do not exclude the possibility of short-term pertubations causing fluctuations in substrate, as Nature can by no means be considered a steady-state chemostat. Examples of temporal $\mathrm{DOC}_{\mathrm{L}}$ variations are available (Fig. 4 and Wright 1988). Second, the models assume 1 compound described by a single $K_{\mathrm{s}}$. However, Billen has extended the use of the model to more complicated situations involving variable $K_{\varsigma}$ values for polymer hydrolysis (Billen 1990) and does not restrict the model to any specific category of substrate (Billen et al. 1990). The application of a 2step decomposition model with 2 different half-saturation constants describing the bacterial affinity to superlabile (L1, low $K_{\mathrm{s}}$ ) and 'just' labile (L2, high $K_{\mathrm{s}}$ ) DOC was also used to model bacterial DOC utilization with reasonable success by Connolly et al. (1992). Their calculated model parameters showed L1 and L2 carbon to be characterized by growth yield and $K_{\mathrm{s}}$ differences resulting in steady-state concentration differences between L1 and L2 of a factor of 10, i.e. the steadystate concentration of a usable substrate is controlled by parameters characterizing bacterial affinities.

The initial question of whether cross-system $\mathrm{DOC}_{\mathrm{L}}$ concentrations are positively related to DOC was answered affirmatively (Fig. 7), so the next question must be whether system-dependent differences of a 'theoretical community $K_{\mathrm{S}}$ for $\mathrm{DOC}_{\mathrm{L}}$ can be accepted as an explanation. The quotation marks are used to signify that such a single constant is only a model parameter. The question more specifically is, can the DOC products in high-productivity systems be expected to be less susceptible to bacteria (e.g. higher $\mathrm{C} / \mathrm{N}$ ratios, more dominated by polymers and complex organics) than DOC produced in oligotrophic systems or can the cross-system differences be explained by physiological features inherent to the bacterial communities?

As mentioned, we have no obvious reasons to expect DOC of autochthonous origin to have better quality in oligotrophic than in eutrophic systems. However, the proximity of most eutrophic systems to terrestrial influences could suggest an input of less available DOC. DOC in rivers is often expected to be rather recalcitrant (Mantoura \& Woodward 1983), so the origin of the allochthonous input is of utmost importance (Kaplan \& Bott 1982, Leff \& Meyer 1991). The results from the present study cannot exclude the suggestion of a general recalcitrant nature of riverine DOC (Fig. 8), because the data may be biased by lack of representativity and waste-water interference. The data with high percentages of $\mathrm{DOC}_{\mathrm{L}}$ were in fact all obtained from rivers which were recipients of either domestic or industrial waste water. Measurements from some major European rivers (e.g. the Seine) are included in the data.

Furthermore, the results from decomposition experiments in a gradient from clearwater to polyhumic lakes in Sweden (Tranvik 1988) and those obtained by Ogura $(1972,1975)$ cannot support an unequal relative $\mathrm{DOC}_{\mathrm{L}}$ availability among systems with different terrestrial influences. In fact, one oceanic decomposition rate constant obtained by Ogura (1972) was among the lowest found and the relative amount of $\mathrm{DOC}_{\mathrm{L}}$ in the lakes studied by Tranvik (1988) did not differ significantly. Although a hypothesis of terrestrial proximity and influence per se cannot be totally rejected as part of an explanation for the range of $\mathrm{DOC}_{\mathrm{L}}$ among systems, the evidence for such a relationship is rather weak and needs further exploration.

Several studies have shown different $K_{\mathrm{s}}$ values for identical compounds in different systems. In a transect through the plume of the Amazon River from coastal to open ocean waters off Brazil, Vaccaro \& Jannasch (1966) found that the community $K_{\mathrm{s}}$ for glucose decreased from about 40 to $100 \mu \mathrm{g} \mathrm{C} \mathrm{I}^{-1}$ at the coast to between 3 and $20 \mu \mathrm{g} \mathrm{Cl}^{-1}$ at the offshore stations. A similar system-dependent difference was found for glucose and acetate, but only as a trend for alanine, by Billen (1984). $K_{\mathrm{s}}$ increased as a function of the utilization rate of the compound in question and thus increased with system productivity. The higher concen- 
trations of amino acids in eutrophic lakes as opposed to more oligotrophic seawater (Fuhrman \& Ferguson 1986, Jørgensen 1986, Münster \& Chróst 1990) can be taken as further indirect evidence for such community differences in $K_{5}$. Thus, $K_{\mathrm{s}}$ for some simple molecules is positively related to the concentration of total DOC. If bacterial communities in environments with high DOC concentrations have lower affinity in general, as exemplified by glucose and acetate, this could offer an explanation for high $\mathrm{DOC}_{\mathrm{L}}$ concentrations. Multiphasic transport systems encompassing low-capacity and high-affinity uptake systems and vice versa have been observed in natural microbial communities (Azam \& Ammerman 1984). Bacteria with high capacity but low affinity for uptake of monomeric compounds might have a competitive advantage over bacteria with low capacity and high affinity in nutrient-rich conditions where the production of organic substrate is high. Such a natural selection concerning $K_{\mathrm{s}}$ would be an analogy to phytoplankton species, where the competitive advantage of low-capacity but high-affinity systems for uptake of inorganic nutrients at low concentrations compared with species with high capacity but low affinity is well documented (Sommer 1983). At higher nutrient concentrations the competitive advantage is the other way around.

Despite the observed variability in $K_{\mathrm{s}}$ the concentration of monomers is very low, and their general higher concentration in eutrophic systems does not seem to explain the total range of observed $D O C_{L}$. Consequently, we suggest the range in $\mathrm{DOC}_{\mathrm{L}}$ concentration to be due mainly to biopolymers, which are made available for assimilation by extracellular enzymatic activity. The activity of extracellular enzymes has been identified as a rate-limiting step in bacterial utilization of DOC (Billen 1990) and a lower affinity in eutrophic systems would result in a higher concentration of polymers. One explanation for an apparent high $K_{\mathrm{s}}$ for extracellular enzymes under eutrophic conditions is that the enzymes are subject to synthesis repression and competitive inhibition by endproducts (Chróst 1990). The effects of repression and/or inhibition are an increase in affinity and lower initial activity and thus higher steady-state concentrations of the substrates. In a high-productivity situation the flux and concentration of small molecules, which are responsible for bacterial production, are higher than in oligotrophic systems and could influence the kinetic behavior of the extracellular enzymes.

Finally, a prolonged period of bacterial nutrient limitation might affect the measured concentrations of $\mathrm{DOC}_{\mathrm{L}}$. The lack of an appropriate nitrogen and phosphorus source could, for a period, perturbate the stoichiometry of bacterial substrate utilization and allow an accumulation of DOC, although the accumulation might be counteracted by a continuation of high uptake but a decrease in growth yield (N. O. G. Jørgensen, N. Kroer \& R. B. Coffin unpubl.). Bacterial nutrient limitation, either by phosphate (Morris \& Lewis 1992), nitrogen or both (Zweifel et al. 1993) has been found, but to our knowledge only in nutrientpoor and low-productivity systems. There is no evidence available which could suggest a higher probability of bacterial nutrient limitation in eutrophic as opposed to oligotrophic systems and thereby influence the positive slope of the $\mathrm{DOC}_{\mathrm{L}}$ versus DOC regression. Some of the temporal fluctuations might, however, be explained by the lack of nutrients.

From the available evidence and the theoretical analysis presented, our conclusion is that the crosssystem difference in $D O C_{L}$ concentrations spanning a factor of about 100 (Fig. 7) is probably caused by a difference in bacterial substrate affinity. A higher 'theoretical community $K_{s}^{\prime}$ for $\mathrm{DOC}_{L}$ in eutrophic as opposed to oligotrophic systems could offer an explanation for the positive empirical correlation of $\mathrm{DOC}_{\mathrm{L}}$ versus DOC. The effect of higher $K_{\mathrm{s}}$ would be higher steadystate concentrations of usable substrate, with respect to both monomeric and polymeric compounds. Shortterm (hours/days) within-system variations are more likely explained by an imbalance between production and consumption rates, while long-term (weeks) variations could result from a succession of bacterial communities with different $K_{\mathrm{s}}$ values (Søndergaard et al. 1995).

Acknowledgements. The useful advice and suggestions of Richard B. Coffin and the referees, and the unpublished results supplied by Paul Kepkay and R. B. Coffin, are very much appreciated. This study was supported by The Danish Natural Sciences Research Council, the Danish SMP programme, and by a Carlsberg Foundation Fellowship at Churchill College, Cambridge.

\section{LITERATURE CITED}

Allen, H. L. (1976). Dissolved organic matter in lakewater: characteristics of molecular weight size-fractionations and ecological implications. Oikos 27:64-70

Aminot, A., El-Sayed, M. A., Kerouel, R. (1990). Fate of the natural and anthropogenic dissolved organic carbon in the macrotidal Elorn Estuary (France). Mar. Chem. 29: $255-275$

Ammerman, J. W., Fuhrman, J. A., Hagström, A., Azam, F. (1984). Bacterioplankton growth in seawater: I. Growth kinetics and cellular characteristics in seawater cultures. Mar. Ecol. Prog. Ser. 18: 31-39

Amon, R. M., Benner, R. (1994). Rapid cycling of high-molecular-weight dissolved organic matter in the ocean. Nature (in press)

Azam, F., Ammerman, J W. (1984). Cycling of organic matter by bacterioplankton in pelagic marine ecosystems: microenvironmental considerations. In: Fasham, M. J. R. (ed.) Flow of energy and material in marine ecosystems. 
Plenum Press, New York, p. 345-360

Azam, F., Fenchel, T., Field, J G., Gray, J. S., Meyer-Reil, L. A., Thingstad, F. (1983). The ecological role of watercolumn microbes in the sea. Mar. Ecol. Prog. Ser, 10 $257-263$

Barber, R. T. (1968). Dissolved organic carbon from deep water resists microbial oxidation. Nature 220: 274-275

Bell, W. H. (1980). Bacterial utilization of algal extracellular products. I. The kinetic approach. Limnol. Oceanogr 25 $1007-1020$

Bertoni, R. (1986). Evaluation of the heterotrophic activity in waters by microanalytical methods. IFREMER Actes Coll. 3: $103-108$

Billen, G. (1984). Heterotrophic utilization and regeneration of nitrogen. In: Hobbie, J. E., Williams, P. J. leB. (eds.) Heterotrophic activity in the sea. Plenum Press, New York, p. $313-355$

Billen, G. (1990). Delayed development of bacterioplankton with respect to phytoplankton: a clue for understanding their trophic relationships. Arch. Hydrobiol Beih. Ergebn. Limnol. 34: 191-201

Billen, G., Fontigny, A. (1987). Dynamics of a Phaeocystisdominated bloom in Belgian coastal waters. II. Bacterioplankton dynamics. Mar. Ecol. Prog. Ser. 37: 249-257

Billen, G., Joiris, C., Wijnant, J., Gillain, G. (1980). Concentration and microbiological utilization of small organic molecules in the Scheldt estuary, the Belgian coastal zone of the North Sea and the English Channel. Estuar. coast. mar. Sci. 11: 279-294

Bilen, G., Servais, P., Becquevort, S. (1990). Dynamics of bacterioplankton in oligotrophic and eutrophic aquatic environments: bottom-up or top-down control? Hydrobiologia 207: $37-42$

Birge, E. A., Juday, C. (1934). Particulate and dissolved organic matter in inland lakes. Ecol. Monogr. 4: 440-474

Bodungen, B. von, Kahler, P. (1994). Dissolved organic carbon in the Atlantic Ocean - regional and seasonal patterns. AGU/ASLO Ocean Sciences Meeting, San Diego. EOS Trans. Am. geophys. Un. 75(3): 106

Børsheim, K. Y., Andersen, S., Johnsen, G. H., Kambestad, E. Ø.. Norland, S. (1988). Primary and bacterial production compared to growth and food requirements of Daphnia longispina in Lake Kvernavatnet, west Norway. J. Plankton Res. 10: 921-939

Brockmann, U. H., Eberlein, K., Junge, H. D., Maier-Reimer, E.,Siebers, D. (1979). The development of a natural plankton population in an outdoor tank with nutrient-poor sea water. II. Changes in dissolved carbohydrates and amino acids. Mar. Ecol. Prog. Ser. 1. 283-291

Carlson, D. J., Brann, M. L., Mague, T H., Mayer, L. M. (1985). Molecular weight distribution of dissolved organic materials in seawater determined by ultrafiltration: a reexamination. Mar. Chem. 16: 155-171

Carpenter, S. R., Kitchell, J. F., Hodgson, J. R. (1985). Cascading trophic interactions and lake productivity. BioSci. 35: $634-639$

Chróst, R. J. (1990). Microbial ectoenzymes in aquatic environments. In: Overbeck, J., Chróst, R. J. (eds.) Aquatic microbial ecology. Springer-Verlag, New York, p. 47-78

Coffin, R. B. (1989). Bacterial uptake of dissolved free and combined amino acids in estuarine waters. Limnol. Oceanogr 34: 531-542

Coffin, R. B., Connolly, J. P., Harris, P. S. (1993). Availability of dissolved organic carbon to bacterioplankton examined by oxygen utilization. Mar. Ecol. Prog. Ser. 101: 9-22

Cole, J. J., Findlay, S., Pace, M. C. (1988). Bacterial production in freshwater and saltwater ecosystem: a cross-system overview. Mar. Ecol. Prog. Ser. 43:1-10

Cole, J. J., McDowell, W. H., Likens, G. E. (1984). Sources and molecular weight of 'dissolved' organic carbon in an oligotrophic lake. Oikos 42:1-9

Connolly, J. P., Coffin, R. B., Landeck, R. E. (1992). Modeling carbon utilization by bacteria in natural water systems. In: Hurst, C. J. (ed.) Modeling the metabolic and physiologic activities of microorganisms. John Wiley \& Sons, Inc., New York, p. 249-276

Crawford, C. C., Hobbie, J. E., Webb, K. L. (1974). The utilization of dissolved free amino acids by estuarine microorganisms. Ecology 55: 551-563

Duursma, E. K. (1963). The production of dissolved organic matter in the sea, as related to the primary gross production of organic matter. Neth. J. Sea Res. 2: 85-94

Findlay, S., Pace, M. L., Lints, D., Howe, K. (1992). Bacterial metabolism of organic carbon in the tidal freshwater Hudson Estuary. Mar. Ecol. Prog. Ser. 89: 147-153

Fuhrman, J. A., Azam, F. (1980). Bacterioplankton secondary production estimates for coastal waters off British Columbia, Antarctica, and California. Appl. environ. Microbiol. 39: $1085-1095$

Fuhrman, J. A., Ferguson, R. L. (1986). Nanomolar concentrations and rapid turnover of dissolved free amino acids in seawater: agreement between chemical and microbiological measurements. Mar. Ecol. Prog. Ser. 33: 237-242

Gasol, J., Vaqué, D. (1993). Lack of coupling between heterotrophic nanoflagellates and bacteria: a general phenomenon across aquatic systems? Limnol. Oceanogr. 38: $657-665$

Hagström, $\AA$, Ammerman, J. W., Henrichs, S., Azam, F. (1984). Bacterioplankton growth in seawater: II. Organic matter utilization during steady-state growth in seawater cultures. Mar. Ecol. Prog. Ser. 18: 41-48

Hagström, А., Blackburn, N. (1994). Organic matter degradation in the microbial food web: a fundamental model. AGU/ASLO Ocean Sciences Meeting, San Diego. EOS Trans. Am. geophys. Un. 75(3): 212

Hama, T., Handa, N. (1983). The seasonal variation of organic constituents in a eutrophic lake, Lake Suva, Japan. Part II Dissolved organic matter. Arch. Hydrobiol. 98: 443-462

Hedges, J. I. (1992). Global biogeochemical cycles: progress and problems. Mar. Chem. 39: 67-93

Hobbie, J. E., Daley, J., Jasper, S. (1977). Use of Nuclepore filters for counting bacteria by fluorescence microscopy. Appl environ. Microbiol. 33: 1225-1228

Ittekot, V. (1982). Variations of dissolved organic matter during a plankton bloom: qualitative aspects based on sugar and amino acid analysis. Mar. Chem. 4: 143-158

Johnson, B. D., Kepkay, P. E. (1992). Colloid transport and bacterial utilization of oceanic DOC. Deep Sea Res. 39: $855-869$

Johnson, B. D., Wangersky, P. J. (1985). Seawater filtration: particle flow and impaction considerations. Limnol. Oceanogr. 30: $966-971$

Jonas, R. B., Tuttle, J. H. (1990). Bacterioplankton and organic dynamics in the lower mesohaline Chesapeake Bay. Appl. environ. Microbiol. 56: 747-757

Jørgensen, N. O. G. (1986). Dissolved organic carbon (DOC) in lakes. In: Riemann, B., Sondergaard, M. (eds.) Carbon dynamics in eutrophic, temperate lakes. Elsevier, Amsterdam, p. 5-25

Jørgensen, N. O. G., Jensen, R. E. (1994). Microbial fluxes of free monosaccharides and total carbohydrates in freshwater determined by PAD-HPLC. FEMS Microbiol. Ecol. 14: $79-94$

Jørgensen, N. O. G., Kroen, N., Coffin, R. B. (1994). Utilization 
of dissolved nitrogen by heterotrophic bacterioplankton: effect of substrate $\mathrm{C} / \mathrm{N}$ ratio. Appl. environ. Microbiol. 60 : 4124-4133

Jumars, P. A., Penry, D. L., Baross, J. A., Perry, M. J., Frost, B. W. (1989). Closing the microbial loop: dissolved carbon pathway to heterotrophic bacteria from incomplete ingestion, digestion and absorption in animals. Deep Sea Res. 36: $483-495$

Kahler, P., Bjornsen, P. K., Lochte, K. (1994). Bacterial growth on natural dissolved organic matter in the Southern Ocean. AGU/ASLO Ocean Sciences Meeting, San Diego. EOS Trans. Am. geophys. Un. 75(3): 177

Kaplan, L. A., Bott, T. L. (1982). Diel fluctuations of DOC generated by algae in a piedmont stream. Limnol. Oceanogr. 27: $1091-1100$

Kepkay, P. E. (1994). Particle aggregation and the biological reactivity of colloids. Mar. Ecol. Prog. Ser 109: 293-304

Keys, A., Christensen, E. H., Krogh, A. (1935). The organic metabolism of sea-water with special reference to the ultimate food cycle in the sea. J. mar. biol. Ass. U.K. 20: 181-196

Kirchman, D. L., Suzuki, Y., Garside, C., Ducklow, H. W. (1991). High turnover rates of dissolved organic carbon during a spring phytoplankton bloom. Nature 352: 612-614

Kristiansen, K., Nielsen, H., Riemann, B, Fuhrman, J. A. (1992). Growth efficiencies of freshwater bacterioplankton. Microb. Ecol. 24: 145-160

Kroer, N. (1993). Bacterial growth efficiency on natural dissolved organic matter. Limnol. Oceanogr. 38: 1282-1290

Krogh, A. (1930). Über die Bedeutung von gelösten organischen Substanzen bei der Ernährung von Wassertieren. Zeitsch. f. vergl. Physiol. 12: 668-681

Krogh, A. (1934a). Conditions of life in the ocean. Ecol. Monogr. 4: 421-429

Krogh, A. (1934b). Conditions of life at great depth in the ocean. Ecol. Monogr. 430-439

Krogh, A., Lange, E. (1932). Quantitative Untersuchungen über Plankton, Kolloide und gelöste organische und anorganische Substanzen in dem Furesee. Int. Rev. ges. Hydrobiol. 26: 20-53

Lee, S., Fuhrman, J. A. (1987). Relationship between biovolume and biomass of naturally derived marine bacterioplankton. Appl environ. Microbiol. 53: 1298-1303

Lee, C., Wakeham, S. G. (1992). Organic matter in the water column: future research challenges. Mar. Chem. 39: $95-118$

Leff, L. G., Meyer, J. L. (1991). Biological availability of dissolved organic carbon along the Ogeechee River. Limnol. Oceanogr. 36: 315-323

Mantoura, R. F. C., Woodward, E. M. S. (1983). Conservative behavior of riverine dissolved organic carbon in the Severn Estuary: chemical and geochemical implications. Geochim. Cosmochim. Acta 47: 1293-1309

Middelboe, M., Nielsen, B., Søndergaard, M. (1992). Bacterial utilization of dissolved organic carbon (DOC) in coastal waters. Determination of growth yield. Arch. Hydrobiol. Beih. Ergebn. Limnol. 37: 51-61

Middelboe, M., Søndergaard, M. (1993). Bacterioplankton growth yield: seasonal variations and coupling to substrate lability and $\beta$-glucosidase activity. Appl. environ. Microbiol. 59: 3916-3921

Morris, D. P., Lewis, W. M. Jr (1992). Nutrient limitation of bacterioplankton growth in Lake Dillon, Colorado, Limnol. Oceanogr. 37: 1179-1192

Münster, U., Chróst, R. J. (1990). Origin, composition and microbial utilization of dissolved organic matter. In: Overbeck, J., Chróst, R. J (eds.) Aquatic microbial ecology.
Springer-Verlag, New York, p. 8-46

Nagata, T., Kirchman, D. L. (1992). Release of macromolecular organic complexes by heterotrophic marine flagellates. Mar. Ecol. Prog. Ser. 83: 233-240

Ochiai, M., Nakajima, T., Hanya, T (1980). Chemical composition of labile fractions in DOM. Hydrobiologia 71: 95-97

Ogura, N. (1972). Rate and extent of decomposition of dissolved organic matter in surface seawater. Mar. Biol. 13: 89-93

Ogura, N. (1975). Further studies on decomposition of dissolved organic matter in coastal seawater Mar. Biol. 31: $101-111$

Pakulski, J. D., Benner, R. (1994). Abundance and distribution of carbohydrates in the ocean. Limnol. Oceanogr. 39: 930-940

Payne, J. W. (1976). Peptides and microorganisms. Adv. Microbiol. Physiol. 13: 55-113

Peltzer, E. T (1994). Distribution and temporal variation of dissolved organic carbon in the equatorial Pacific Ocean. AGU/ASLO Ocean Sciences Meeting, San Diego. EOS Trans. Am. geophys. Un. 75(3): 49

Pütter, A. (1908). Die Ernährung der Wassertiere. Zeitsch. f. allg. Physiol. 7: 283-320

Pütter, A. (1911). Die Ernährung der Wassertiere durch gelöste organische Verbindungen. Pflüger's Arch. f. gesam. Physiol. 137: 595-621

Riemann, B., Søndergaard, M. (1986). Bacteria. In: Riemann, B., Sondergaard, M. (eds.) Carbon dynamics in eutrophic, temperate lakes. Elsevier, Amsterdam, p. 127-197

Sanders, R. W., Seitzinger, S. P., Jahn, R. (1994). Biological utilization of riverine dissolved organic nitrogen by estuarine organisms, including a comparison of persulfate and hightemperature combustion methods. AGU/ASLO Ocean Sciences Meeting, San Diego. EOS Trans. Am. geophys. Un. 75(3): 106

Sepers, A. B. J. (1977). The utilization of dissolved organic compounds in aquatic environments. Hydrobiologia 52: $39-54$

Servais, P., Anzil, A., Ventresque, C. (1989). A simple method for determination of biodegradable dissolved organic carbon in water. Appl. environ. Microbiol. 55: 2732-2734

Servais, P., Billen, G., Hascoët, M.-C. (1987). Determination of the biodegradable fraction of dissolved organic matter in waters. Water Res. 21: 445-450

Sharp, J. H. (1973). Size classes of organic carbon in seawater Limnol. Oceanogr. 18: 441-447

Sharp, J. H. (1993). Procedures subgroup report. Mar. Chem. $41: 37-49$

Sharp, J. H., Benner, R., Bennett, L., Carlson, C. A., Dow, R., Fitzwater, S. E. (1993). Re-evaluation of high temperature combustion and chemical oxidation measurements of dissolved organic carbon in seawater. Limnol. Oceanogr. 38: $1774-1782$

Sieburth, J. McN., Johnson, K. M., Burney, C. M., Lavoie, D. M. (1977). Estimation of the in situ rates of heterotrophy using diurnal changes in dissolved organic matter and growth rates of picoplankton in diffusion culture. Helgoländer wiss. Meeresunters. 30:565-574

Simon, M., Azam, F. (1989). Protein content and protein synthesis rates of planktonic marine bacteria. Mar. Ecol. Prog. Ser. 51: 201-213

Sokal, R. R., Rohlf, F. J (1981). Biometry, 2nd edn. Freeman and Co., San Francisco

Sommer, U. (1983). Nutrient competition between phytoplankton species in multispecies chemostat experiments. Arch. Hydrobiol. 96: 399-416

Søndergaard, M. (1984). Dissolved organic carbon in Danish 
lakes: concentration, composition, and lability. Verh. int. Verein. theor angew, Limnol. 22: 780-784

Sondergaard, M., Borch, N. H. (1992) Decomposition of dissolved organic carbon (DOC) in lakes. Arch. Hydrobiol. Beih. Ergebn. Limnol. 37: 9-20

Sondergaard, M., Hansen, B., Markager, S. (1995). Dynamics of dissolved organic carbon lability in a eutrophic lake. Limnol. Oceanogr. (in press)

Sondergaard, M., Middelboe, M. (1993). Measurements of particulate organic carbon: a note on the use of glass fiber (GF/F) and Anodisc filters. Arch. Hydrobiol. 127: 73-85

Sondergaard, M., Schierup, H.-H. (1982). Dissolved organic carbon during a spring diatom bloom in Lake Mossø, Denmark. Water Res. 16: 815-821

Tranvik, L. J. (1988). Availability of dissolved organic carbon for planktonic bacteria in oligotrophic lakes of differing humic content. Microb. Ecol. 16: 311-322

Tranvik, L. J., Höfle, M. G. (1987). Bacterial growth in mixed cultures on dissolved organic carbon from humic and clear waters. Appl. environ. Microbiol. 53: 482-488

Tulonen, T (1993). Bacterial production in a mesohumic lake estimated from $\left.\right|^{14} \mathrm{C}$ leucine incorporation rate. Microb. Ecol. 26: 201-217

Vaccaro, R. F., Jannasch, H. W. (1966). Studies on heterotrophic activity in seawater based on glucose assimilation. Limnol. Oceanogr. 11: 596-607

Wafar, M., Le Corre, P., Birrien, J.-L. (1984). Seasonal changes of dissolved organic matter (C, N, P) in permanently well

This review was submitted to the editor mixed temperate waters. Limnol. Oceanogr. 29: 1127-1132

Wells, M. L., Goldberg, E. D. (1991). Occurrence of small colloids in sea water. Nature 353: $342-344$

Williams, P. J. leB. (1973). The validity of the application of simple kinetic analysis to heterogeneous microbial populations. Limnol. Oceanogr. 18: 159-165

Williams, P. J. leB. (1981). Incorporation of microheterotrophic processes into the classical paradigm of the planktonic food web. Kieler. Meeresforsch. Sonderh. 5: 1-28

Williams, P. J. leB. (1990). The importance of losses during microbial growth: commentary on the physiology, measurement and ecology of the release of dissolved organic material. Mar. microb. Food Webs 4: 175-206

Wright, R. T (1988). Methods for evaluating the interaction of substrate and grazing as factors controlling planktonic bacteria. Arch. Hydrobiol. Beih. Ergebn. Limnol. 31 $229-242$

Wright, R. T., Coffin, R. B., Lebo, M. E. (1987). Dynamics of planktonic bacteria and heterotrophic microflagellates in the Parker Estuary, northern Massachusetts. Cont. Shelf Res. 7: 1383-1397

Wright, R. T., Hobbie, J. E. (1966). Use of glucose and acetate by bacteria and algae in aquatic ecosystems. Ecology 47 : $447-468$

Zweifel, U. L., Norrman, B., Hagström, $\AA$. (1993). Consumption of dissolved organic carbon by marine bacteria and demand for inorganic nutrients Mar. Ecol. Prog. Ser. 101. $23-32$

Manuscript first received: May 16, 1994

Revised version accepted: October 24, 1994 